\title{
Seasonal rainfall variability in the southern Mediterranean border: Observations, regional model simulations and future climate projections
}

\author{
Sabrina TAÏBI ${ }^{1 *}$, Mohamed MEDDI $^{2}$ and Gil MAHÉ ${ }^{3}$ \\ ${ }^{1}$ Université Saad Dahlab-Blida1, Département des sciences de l'eau et environnement, Algérie. \\ ${ }^{2}$ Ecole Nationale Supérieure d'Hydraulique (ENSH), Laboratoire Génie de l'eau et l'environnement, Blida, Algérie. \\ ${ }^{3}$ HydroSciences Montpellier Université, IRD, Montpellier, France. \\ *Corresponding author; emails: taibisabrina86@gmail.com; s.taibi@univ-blida.dz
}

Received: November 24, 2017; accepted: November 16, 2018

\begin{abstract}
RESUMEN
En los últimos años se ha dado especial atención a la precipitación y a la variación en los escenarios de cambio climático, al modelar estos fenómenos a diferentes escalas de tiempo. Los modelos climáticos regionales permiten evaluar el impacto del cambio climático a escala regional y local. Este estudio tiene como objetivo en primer lugar el analizar la variabilidad de las precipitaciones en el norte de Argelia; y, en segundo lugar, evaluar la futura variabilidad estacional de la precipitación utilizando modelos climáticos regionales del proyecto ENSEMBLE. Se utilizó una prueba estadística y el método de sesgo. El análisis de variabilidad estacional utilizando la prueba de Pettitt durante el periodo de referencia (1961-1990) reveló una disminución significativa de las precipitaciones a partir de la década de 1970 en las estaciones de Tenes y Oran, ubicadas en la parte noroeste de Argelia. Esta reducción se produjo durante los meses de invierno (diciembre y enero) y primavera (marzo y abril), asociada principalmente a la disminución de la frecuencia de días con precipitaciones en el rango de 10-20 y 20-50 mm, mientras que en la región oriental se registró un aumento de las precipitaciones. Los datos simulados de 12 modelos climáticos regionales se compararon primero con datos observacionales durante el periodo de referencia utilizando el método de sesgo. Posteriormente, se proyectó la variabilidad estacional de la precipitación en los periodos 2021-2050 y 2070-2099. En general, los modelos subestiman las estaciones húmedas y sobreestiman las estaciones secas durante el periodo estudiado; asimismo, simulan una disminución significativa de las precipitaciones futuras en invierno y primavera en ambos periodos proyectados. Es necesario realizar nuevos estudios para explicar la subestimación de los modelos, así como reconsiderar las incertidumbres que afectan los resultados de este trabajo.
\end{abstract}

\section{ABSTRACT}

Particular attention has been given in recent years to precipitation and variations in climate change scenarios by modeling these phenomena at different timescales. Regional climate models enable assessing the impact of climate change at the regional and local scales. This study aims, firstly, to analyze the rainfall variability in northern Algeria, and secondly, to evaluate future seasonal rainfall variability using regional climate models of the ENSEMBLE project. A statistical test and the bias method have been used for this study. Analysis of rainfall variability using the Pettitt test during the reference period (1961-1990) reveals a significant decrease of rainfall since the 1970s at the Tenes and Oran stations, located in the northwest of Algeria. This decrease occurs during the months of December and January (in winter), and March and April (in spring), and is associated to a reduction of 10-20 and 20-50 mm of daily rainfall, respectively, while the rainfall increases in the eastern region. Simulated data of 12 regional climate models have been compared to observations carried out during the reference period (1961-1990) using the bias method. Future seasonal rainfall variability was analyzed for two projection periods: 2021-2050 and 2070-2099. Most often, models underestimate the wet seasons and overestimate the dry seasons during the reference period. The models simulated a significant 
decrease of future rainfall in winter and spring over the two projected periods. Further investigations must be conducted to explain the underestimation of the models. It is also important to reconsider uncertainties that affect the results of this study.

Keywords: Rainfall variability, regional climate models, Algeria, Mediterranean basin.

\section{Introduction}

Particular attention has been given in recent years to precipitation and variations in climate change scenarios by modeling these phenomena at different timescales. Global climate models simulate past and future climate evolution around the world. Their resolution of several hundreds of kilometers is sufficient to simulate the large-scale dynamics of the atmosphere at the planet's scale and produce average temperature or rainfall projections; however, they are unable to reproduce regional features. In order to study the climate evolution of the Mediterranean basin, it is necessary to use regional climate models (RCM). Since the fourth IPCC report was published in 2007 (IPCC, 2007), regionalized simulations are improving and can refine trends in the Mediterranean basin. The RCMs allow high resolution simulations to assess the impact of climate change at the regional and local scales. In the Euro-Mediterranean region, several projects yielded regional climate model simulation outputs ready for research teams to use. This was the goal of the Prediction of Regional Scenarios and Uncertainties for Defining European Climate Change Risks and Effects (PRUDENCE) project (http://prudence.dmi.dk) concluded in 2004; of the Statistical and Regional Dynamical Downscaling of Extremes for European Regions (STARDEX) project (http://www.cru.uea.ac.uk/projects/stardex/), based on the simulations of PRUDENCE finished in 2005; and of the ENSEMBLE-based Predictions of Climate Changes and their Impacts (ENSEMBLES) project (http://www.ensembles-eu.org/) finalized in 2009. Eventually, the Coordinated Regional Climate Downscaling Experiment (CORDEX) (http://www. medcordex.eu) succeeded the ENSEMBLES project.

The assessment of the impact of climate change on the hydrological variability of the Mediterranean basin using climate models has been widespread in river basins in France (Quintana Seguí et al., 2010), Spain (Majone et al., 2012; Giménez et al. 2016), Italy (Senatore et al., 2011) and across the
Mediterranean basin (Sánchez-Gómez et al., 2009; Dubois et al., 2012; Milano et al., 2012, 2013; Hertig and Tramblay, 2016; Paeth et al., 2016; Alemseged and Tom, 2015). However, few studies have been interested in the details in North Africa (Driouech et al., 2010; Tramblay et al., 2012; Bargaoui et al., 2014; Filahi et al., 2017).

Giorgio and Lionello (2008) analyzed rainfall data from the PRUDENCE climate model simulations in different regions of the Mediterranean basin (north, south, east, west, central). Future projections of rainfall for 2100 indicate a reduction of $15 \%$ for the wet season (September to May) and 30\% in summer. This will affect southern parts of the Mediterranean. Zanis et al. (2008) assessed the simulated rainfall of nine PRUDENCE-RCM outputs for Greece for the 1961-1990 and 2071-2100 periods. The nine RCMs simulate a decrease of future rainfall of about $14 \%$ in winter, $57 \%$ in summer and $15 \%$ for annual rainfall. Coppola and Giorgi (2010) also discussed the simulated rainfall from PRUDENCE-RCM for the 1961-1990 and 2071-2100 periods in Italy. Future projections show a decline of rainfall in summer for the whole country $(-40 \%)$ while winter rainfall is modelled to increase in the north and decrease in the south.

Tramblay et al. (2012) assessed the performance of the ENSEMBLES regional climate models for past and future annual and extreme rainfall in Morocco. They showed a great variability in the performance of the RCMs to reproduce the seasonal cycle and extreme rainfall of the different stations. Overall, there is a good model convergence towards a decrease in rainfall for the Atlantic stations. For the Mediterranean stations, the projected changes are difficult to assess due to the great variability. In Tunisia, Bargaoui et al. (2014) assessed the outputs of six ENSEMBLES models for the 1961-2000 control period and for two projection periods, 2011-2050 and 2051-2090. They found that, on average, the model outputs underestimate seasonal precipitation 
by $20 \%$. The discrepancy between model outputs and observations depends on the season. For the future, in summer and autumn the different models do not project major changes in seasonal distributions. However, for winter and spring, all the model simulations show a significant decrease in precipitation for the whole country. In this study, following an analysis of past observed rainfall, in order to establish the actual knowledge of spatial and temporal rainfall variability in the study area, we assess the simulated seasonal rainfall of the ENSEMBLE-RCM outputs in northern Algeria during the 1961-1990 reference period and analyze future simulations of validated models during the two projection periods, 2021-2050 and 2070-2099.

\section{Materials and methods}

\subsection{Study area and data set}

Northern Algeria is characterized by a Mediterranean climate in coastal regions and a semi-arid climate in the highland plateaus. Altitudes are higher in the east than in the west, which creates an east-west rainfall gradient. Precipitation in northern Algeria shows a high spatial and temporal variability (Laborde, 1998; Meddi and Hubert, 2003; Meddi and Meddi, 2009; Taibi et al., 2013). The average rainfall varies from $689 \mathrm{~mm} \mathrm{yr}^{-1}$ in Annaba (east) to $377 \mathrm{~mm} \mathrm{yr}^{-1}$ in Oran (west) during the reference period (Table I).

Many studies have shown a significant decrease in the temporal variability of rainfall in northwest Algeria (Medjerab and Henia, 2005; Meddi and Meddi, 2007; Meddi and Talia, 2007; Meddi and Hubert, 2003; Bekkoussa et al., 2008; Meddi et al., 2010; Taibi and Souag, 2011). This decrease is mostly observed during winter and spring (Taibi et al., 2013).

To assess the ability of regional climate models to reproduce rainfall variability in northern Algeria, rain gauge stations, where daily rainfall time series were lacking the least observations since 1961, were selected (Fig. 1). The four selected stations are representative of three coastal regions of northern Algeria which present different rainfall regimes, as highlighted by Taibi et al. (2017): the eastern region (Annaba station), the central region (Algiers and Tenes stations) and the western region (Oran station).

Table I. Statistical characteristics at rain gauges stations during the reference period (1961-1990).

\begin{tabular}{lcccc}
\hline Stations & $\begin{array}{c}\text { Minimum } \\
(\mathrm{mm}) \mathrm{yr}^{-1}\end{array}$ & $\begin{array}{c}\text { Maximum } \\
(\mathrm{mm}) \mathrm{yr}^{-1}\end{array}$ & $\begin{array}{c}\text { Average } \\
(\mathrm{mm}) \mathrm{yr}^{-1}\end{array}$ & $\begin{array}{c}\text { Coefficient } \\
\text { of variation }\end{array}$ \\
\hline Annaba & 320 & 1171 & 689 & 0.29 \\
Algiers & 278 & 1127 & 615 & 0.27 \\
Ténès & 356 & 1112 & 566 & 0.29 \\
Oran & 173 & 633 & 373 & 0.31 \\
\hline
\end{tabular}

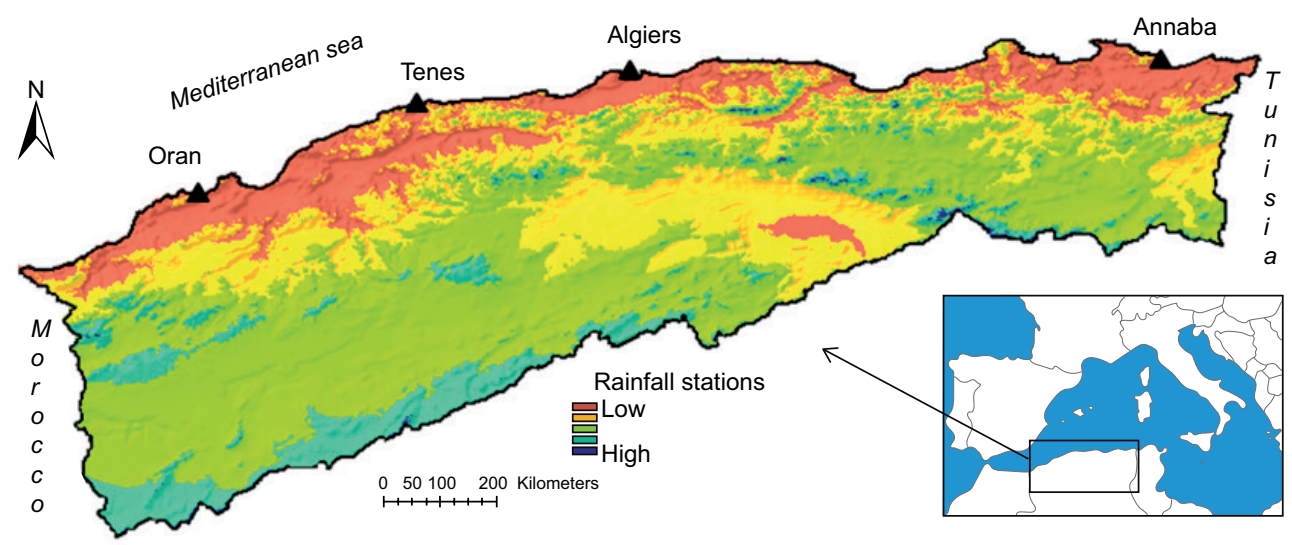

Fig. 1. Geographic location of the study area and rainfall network. 
The characteristics of the rainfall stations are presented in Table II. The daily data was obtained from the National Agency of Water Resources (ANRH) and the National Office of Meteorology (ONM).

Table II. Geographic characteristics of rainfall stations (decimal degrees).

\begin{tabular}{lcccr}
\hline Stations & Origin & Longitude & Latitude & $\begin{array}{r}\text { Altitude } \\
(\mathrm{m})\end{array}$ \\
\hline Algiers & ONM & $3.06 \mathrm{E}$ & $36.41 \mathrm{~N}$ & 25 \\
Annaba & ONM & $7.49 \mathrm{E}$ & $36.50 \mathrm{~N}$ & 3 \\
Oran & ONM & $0.36 \mathrm{~W}$ & $35.1 \mathrm{~N}$ & 90 \\
Ténès & ANRH & $1.32 \mathrm{E}$ & $36.52 \mathrm{~N}$ & 5 \\
\hline
\end{tabular}

The ENSEMBLES project includes 12 regional climate models (Table III). The climate models used provide high-resolution data of simulated rainfall for $25 \times 25 \mathrm{~km}$ square areas for the reference period and for the two projected periods. The simulated rainfall of each model was then updated and compared to observed data from northern Algeria.

\subsection{Methods}

\subsubsection{Pettitt test}

Pettitt's test (1979) is used to detect a single abrupt change in a time series with continuous data. In our case it was used to detect a potential rupture in rainfall time series for the four rainfall stations of northern
Algeria during the 1961-1990 period. This test formulates two hypotheses: $H_{0}$, according to which the $T$ variables follow one or more distributions that have the same location parameter (no change); and $H_{1}$, when a change-point exists. The non-parametric statistic is defined as:

$$
K_{T}=\max \left|U_{t, T}\right|
$$

where

$U_{t, T}=\sum_{i=1}^{t} \sum_{j=t+1}^{T} \operatorname{sgn}\left(X_{i}-X_{j}\right)$

The change-point of the time series is located at $K_{\mathrm{T}}$, provided that the statistic is significant. The significance probability of $K_{\mathrm{T}}$ is approximated for $\mathrm{p}$ $\leq 0.05$ with

$p=2 \exp \left(\frac{-6 K_{T}^{2}}{T^{3}+T^{2}}\right)$

Pettitt's test is one of the most non-parametric tests used to detect a rupture within time series of hydro-climatological data. Several studies have used this test to analyze rainfall variability in northern Algeria (Meddi and Meddi, 2007; Bekkoussa et al., 2008; Meddi et al., 2010; Taibi et al., 2013; etc.).

\subsubsection{Bias method}

RCM model outputs are evaluated by calculating the difference between simulated $\left(\bar{R}_{\text {sim }}\right)$ and observed $\left(\bar{R}_{\text {Obs }}\right)$ seasonal rainfall using the bias method. Many

Table III. Name of regional climate models (RCM), institution, and acronym.

\begin{tabular}{lll}
\hline RCM & Institution & Acronyms \\
\hline HIRAM & Danish Meteorological Institute & DMI \\
RCA & Swedish Meteorological and Hydrological Institute (SMHI) & SMHI \\
HadRM3.0 & UK Met Office, & \\
& Hadley Centre for Climate Prediction and Research & HC \\
ALADIN & Météo-France & CNRM \\
& Czech Hydrometeorological Institute & CHMI \\
REMO & Max-Planck-Institute for Meteorology & MPI \\
CLM & Swiss Institute of Technology & ETHZ \\
& GKSS Forschungszentrum Geesthacht GmbH & GKSS \\
ReMCG & The Abdus Salam International Centre for Theoretical Physics & ICTP \\
RCA3 & Instituto Nacional de Meteorología & INM \\
PROMES & Universidad de Castilla La Mancha & UCLM \\
CMCR & OURANOS & OURANOS \\
\hline
\end{tabular}


studies have used this method for the same analysis (Tramblay et al., 2012; Bargaoui et al., 2014; Alemseged et al., 2015; Giménez et al., 2016; Hertig and Tramblay, 2016; Paeth et al., 2016).

Bias $=\frac{\bar{R}_{\text {sim }}-\bar{R}_{\text {Obs }}}{\bar{R}_{O b s}}$

\section{Results}

\subsection{Rainfall variability analysis}

\subsubsection{Seasonal rainfall variability}

Monthly temperature and rainfall time series have been used to draw climatograms of each station studied. Climatograms usually represent precipitation $(\mathrm{P})$ on the left vertical axis and temperature (T) on the right. It is also necessary to observe the following rule: the precipitation value is equal to two times the temperature value $(\mathrm{P}=2 \mathrm{~T})$. Fig. 2 shows a common climatogram of the four stations studied. The climatogram shows a cold/humid period from November to April $(\mathrm{P}>2 \mathrm{~T}$, as already mentioned by Meddi, 2013), while the warm/dry season lasts from June to September $(\mathrm{P}<2 \mathrm{~T})$. The months of May and October are the intersection point between $\mathrm{P}$ and $2 \mathrm{~T}$ and can also be considered as transition periods, which can be alternatively warm/dry or cold/humid from one year to another (Khomsi et al., 2012).

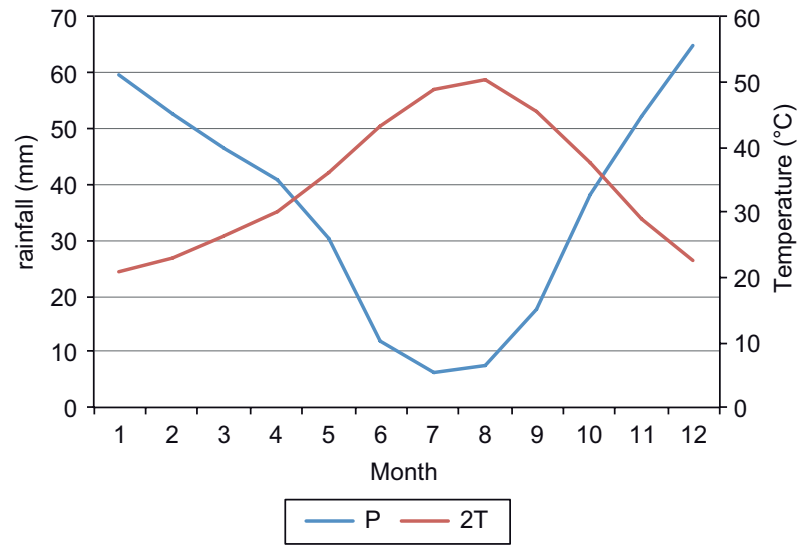

Fig. 2. Climatogram of the study area.

The variability of monthly precipitation (Fig. 3) over the reference period (1961-1990) shows that at the four stations winter is the rainiest season, having $40 \%$ of the annual rainfall (Table IV), while autumn and spring have between $25 \%$ and $30 \%$ (Table IV). It appears that $95 \%$ of the annual rainfall is observed during autumn, winter and spring. In winter, rainfall in Oran $(150 \mathrm{~mm})$ is $40 \%$ less than rainfall in Annaba and Algiers (more than $250 \mathrm{~mm}$ ) (Fig. 3). This difference may be explained by topography, since altitudes are higher in the northeast than in the west. Many studies have shown the importance of the spatial variability of rainfall from east to west (Laborde, 1998; Meddi and Hubert, 2003; Meddi and Meddi, 2009; Taibi et al., 2013). The Algerian mountains are the prolongation of the Atlas Mountains in Morocco, and the whole mountain range, stretching from the southwest to the northeast of the Maghreb, dramatically reduces rainfall coming from the Atlantic towards eastern Algeria. The slopes of the northeastern region of Algeria are generally well exposed to rains coming from Europe (Taibi et al., 2017). On the other hand, the droughts that Algeria has experienced since 1975 have significantly affected the rainfall variability in western Algeria, while the east shows a stable rainfall distribution (Bekoussa, 2008; Meddi et al., 2010; Taibi et al., 2017).

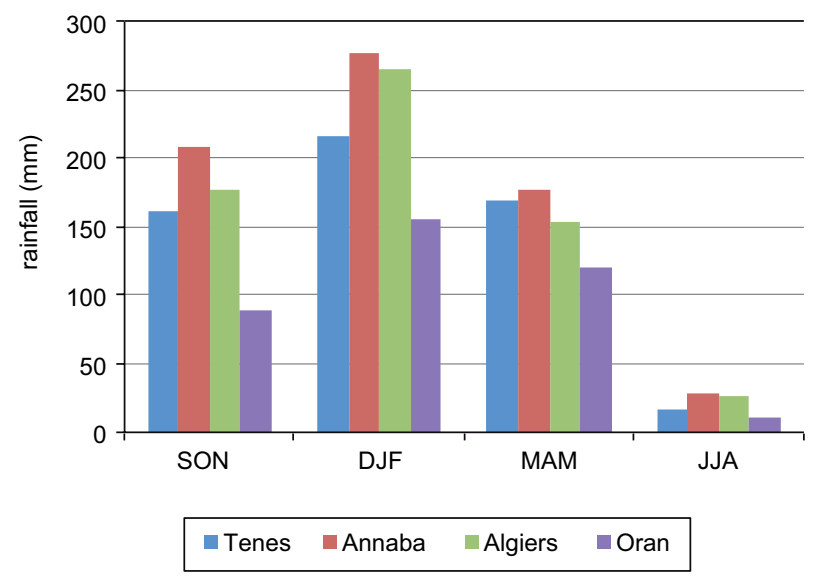

Fig. 3. Average seasonal rainfall in Annaba, Algiers, Tenes, and Oran during the period 1961-1990.

To analyze the temporal variability of seasonal rainfall, the non-parametric Pettitt test has been applied to rainfall time series. For the Tenes and Oran stations, a reduction of rainfall of about $43 \%$ in winter and $38 \%$ in spring are observed (Table V). The rupture date is 1972 for Tenes and 1976 for Oran. 
Table IV. Percentage of seasonal rainfall with respect to annual rainfall.

\begin{tabular}{lcccc}
\hline Stations & SON & DJF & MAM & JJA \\
\hline Annaba & 28 & 43 & 25 & 4 \\
Algiers & 30 & 40 & 26 & 4 \\
Tenes & 29 & 38 & 30 & 3 \\
Oran & 24 & 41 & 32 & 3 \\
\hline
\end{tabular}

Table V. Seasonal rainfall trend regarding Pettitt's test (stationary stations are not included).

\begin{tabular}{cccc}
\hline Stations Pettitt & $\begin{array}{c}\text { Mean before } \\
(\mathrm{mm}\end{array}$ & $\begin{array}{c}\text { Mean after } \\
(\mathrm{mm}\end{array}$ & $\begin{array}{c}\text { Difference } \\
(\%)\end{array}$ \\
$\left.3-\mathrm{month}^{-1}\right)$ & $\left.3-\mathrm{month}^{-1}\right)$ & \\
\hline
\end{tabular}

\begin{tabular}{lllll}
\hline \multicolumn{5}{c}{ Tenes } \\
\hline SON & \multicolumn{3}{c}{ } & \\
DJF & 1972 & 294 & 166 & -43 \\
MAM & & & & \\
JJA & \multicolumn{3}{c}{ Oran } \\
\hline
\end{tabular}

\begin{tabular}{lllll}
\hline \multicolumn{5}{c}{ Oran } \\
\hline SON & & & & \\
DJF & & & 92 & -39 \\
MAM & 1976 & 149 & & \\
JJA & & & \\
\hline
\end{tabular}

The results of Pettitt's test highlight a decrease in rainfall during the wet season, particularly in December, January, March, and April in the Oran and Tenes stations (Table VI). Even if the rupture appears only in winter in Tenes (Table V), the month of April shows a significant reduction in rainfall of about $40 \%$ (Table VI). For the Oran station, although the main decrease takes place during spring, rainfall also significantly decreases in December by about $32 \%$. On the contrary, in the east of the country, in Annaba, an increase of rainfall of more than $100 \%$ is observed for November and $80 \%$ for March during the 19611990 reference period.

\subsubsection{Daily rainfall variability}

To better understand the monthly rainfall variability, we analyzed the evolution of the number of wet days. Taibi et al. (2017) analyzed the frequency trend of wet days for different percentiles, and rainfall classes during the 1940-2010 period for the same stations as those used in this study. The results showed a negative but not significant trend in Algiers and Oran, and a positive but not significant trend in Annaba. Only the Tenes station showed a significant decrease in the number of rainy days.

In this work we analyze the evolution of the frequency of rainy days for five rainfall classes for

Table VI. Monthly rainfall trend regarding Pettitt's test (stationary stations are not included).

\begin{tabular}{|c|c|c|c|c|c|c|c|c|c|}
\hline Pettitt test & Sept & Oct & Nov & Dec & Jan & Feb & Mar & Apr & May \\
\hline \multicolumn{10}{|c|}{ Annaba } \\
\hline $\begin{array}{l}\text { Year of break } \\
\text { Mean before }\left(\mathrm{mm} \mathrm{month} \mathrm{m}^{-1}\right) \\
\text { Mean after }\left(\mathrm{mm} \text { month }^{-1}\right) \\
\text { Difference }(\%)\end{array}$ & & & $\begin{array}{r}1974 \\
44 \\
101 \\
103\end{array}$ & & & & $\begin{array}{r}1970 \\
43 \\
78 \\
80\end{array}$ & & \\
\hline \multicolumn{10}{|c|}{ Oran } \\
\hline $\begin{array}{l}\text { Year of break } \\
\text { Mean before }\left(\mathrm{mm} \mathrm{month} \mathrm{m}^{-1}\right) \\
\text { Mean after }\left(\mathrm{mm} \text { month }^{-1}\right) \\
\text { Difference }(\%)\end{array}$ & & & & $\begin{array}{r}1976 \\
73 \\
49 \\
-32 \\
\end{array}$ & & & $\begin{array}{r}1976 \\
55 \\
30 \\
-45 \\
\end{array}$ & $\begin{array}{r}1976 \\
55 \\
31 \\
-44 \\
\end{array}$ & \\
\hline \multicolumn{10}{|c|}{ Tenes } \\
\hline $\begin{array}{l}\text { Year of break } \\
\text { Mean before }\left(\mathrm{mm} \mathrm{month} \mathrm{m}^{-1}\right) \\
\text { Mean after }\left(\mathrm{mm} \text { month }^{-1}\right) \\
\text { Difference }(\%)\end{array}$ & & & & $\begin{array}{r}1972 \\
122 \\
69 \\
-43\end{array}$ & $\begin{array}{r}1972 \\
101 \\
58 \\
-43\end{array}$ & & & $\begin{array}{r}1972 \\
72 \\
44 \\
-40\end{array}$ & \\
\hline
\end{tabular}


each month during the study period (1961-1990). The selected interval of rainfall classes are 1-5, 5-10, 10-20, 20-50 and $>50 \mathrm{~mm}$. These classes were used in the last studies by Taibi et al. (2017).

Pettitt's statistical test applied for each rainfall class and month shows an increase in the number of wet days in Annaba (Table VII) during November, March and April, which is well correlated with the rupture date for the monthly rainfall time series. The increase of the number of wet days is observed for the rainfall classes of 5-10, 10-20, and 20-50 mm day ${ }^{-1}$ in November, 5-10 and 10-20 mm day ${ }^{-1}$ in March, and only for the rainfall class of 5-10 $\mathrm{mm}^{-1}$ day $^{-1}$ in April (Table VII).
In Algiers, the number of annual wet days has decreased by $30 \%$ since 1974 for the rainfall class $>50 \mathrm{~mm} \mathrm{month}^{-1}$, but this change does not appear in any month, most probably because of the low number of wet days for this rainfall interval (Table VIII).

In Tenes there is a decrease in the number of wet days for most of the rainfall classes. The decrease of the number of wet days in December since 1973 for the $1-5 \mathrm{~mm}$ day $^{-1}$ class is $58 \%$. There is no change for the $5-10 \mathrm{~mm}$ rainfall class. The decrease of the number of wet days since 1973 for the 10-20 mm day ${ }^{-1}$ rainfall class is $41 \%$ without any change for individual months. For the $20-50 \mathrm{~mm}^{\text {day }}{ }^{-1}$ class, a decrease

Table VII. Trend of wet days frequency in Annaba for each month.

\begin{tabular}{|c|c|c|c|c|c|c|c|c|c|c|}
\hline $\begin{array}{l}\text { Rainfall } \\
\text { interval }\left(\mathrm{mm} \mathrm{day}^{-1}\right)\end{array}$ & Pettitt test & Oct & Nov & Dec & Jan & Feb & Mar & Apr & May & Total \\
\hline $1<\mathrm{R}<5$ & - & - & - & - & - & - & & & - & \\
\hline $5<\mathrm{R}<10$ & $\begin{array}{l}\text { Year of break } \\
\text { Mean before } \\
\text { Mean after } \\
\text { Difference (\%) }\end{array}$ & $\begin{array}{l}- \\
- \\
-\end{array}$ & $\begin{array}{c}1974 \\
1.154 \\
3.176 \\
175\end{array}$ & $\begin{array}{l}- \\
- \\
-\end{array}$ & $\begin{array}{l}- \\
- \\
-\end{array}$ & $\begin{array}{l}- \\
- \\
-\end{array}$ & $\begin{array}{c}1970 \\
1.444 \\
3.048 \\
111\end{array}$ & $\begin{array}{c}1975 \\
1.267 \\
2.6 \\
105\end{array}$ & $\begin{array}{l}- \\
- \\
-\end{array}$ & $\begin{array}{c}1970 \\
14.2 \\
20.45 \\
44\end{array}$ \\
\hline $10<\mathrm{R}<20$ & $\begin{array}{l}\text { Year of break } \\
\text { Mean before } \\
\text { Mean after } \\
\text { Difference (\%) }\end{array}$ & $\begin{array}{l}- \\
- \\
-\end{array}$ & $\begin{array}{c}1974 \\
1.1 \\
2.0 \\
87\end{array}$ & $\begin{array}{l}- \\
- \\
-\end{array}$ & $\begin{array}{l}- \\
- \\
-\end{array}$ & $\begin{array}{l}- \\
- \\
-\end{array}$ & $\begin{array}{c}1970 \\
1.3 \\
2.2 \\
70\end{array}$ & $\frac{-}{-}$ & $\begin{array}{l}- \\
- \\
-\end{array}$ & $\begin{array}{c}1974 \\
12.47 \\
17.08 \\
37\end{array}$ \\
\hline $20<\mathrm{R}<50$ & $\begin{array}{l}\text { Year of break } \\
\text { Mean before } \\
\text { Mean after } \\
\text { Difference (\%) }\end{array}$ & $\begin{array}{l}- \\
- \\
-\end{array}$ & $\begin{array}{c}1974 \\
0.133 \\
1 \\
652\end{array}$ & $\begin{array}{l}- \\
- \\
-\end{array}$ & $\begin{array}{l}- \\
- \\
-\end{array}$ & $\begin{array}{l}- \\
- \\
-\end{array}$ & $\frac{-}{-}$ & $\frac{-}{-}$ & $\begin{array}{l}- \\
- \\
-\end{array}$ & $\frac{-}{-}$ \\
\hline $\mathrm{R}>50$ & - & - & - & - & - & - & - & - & - & - \\
\hline
\end{tabular}

Table VIII. Trend of the frequency of wet days for each month in Algiers.

\begin{tabular}{|c|c|c|c|c|c|c|c|c|c|c|}
\hline $\begin{array}{l}\text { Rainfall } \\
\text { interval }\left(\mathrm{mm} \mathrm{day}^{-1}\right)\end{array}$ & Pettitt test & - & Nov & Dec & Jan & Feb & Mar & Apr & May & Total \\
\hline $1<\mathrm{R}<5$ & - & - & - & - & - & - & - & - & - & - \\
\hline $5<\mathrm{R}<10$ & - & - & - & - & - & - & - & - & - & - \\
\hline $10<\mathrm{R}<20$ & - & - & - & - & - & - & - & - & - & - \\
\hline $20<\mathrm{R}<50$ & - & - & - & - & - & - & - & - & - & - \\
\hline $\mathrm{R}>50$ & $\begin{array}{l}\text { Date of break } \\
\text { Mean before } \\
\text { Mean after } \\
\text { Difference \% }\end{array}$ & $\begin{array}{l}- \\
- \\
-\end{array}$ & $\begin{array}{l}- \\
-\end{array}$ & $\begin{array}{l}- \\
-\end{array}$ & $\begin{array}{l}- \\
-\end{array}$ & $\begin{array}{l}- \\
- \\
-\end{array}$ & $\begin{array}{l}- \\
-\end{array}$ & $\begin{array}{l}- \\
-\end{array}$ & $\begin{array}{l}- \\
-\end{array}$ & $\begin{array}{c}1974 \\
1.357 \\
0.375 \\
-30\end{array}$ \\
\hline
\end{tabular}


of the number of wet days is observed in April since 1978 , but there is no change for the annual time series and finally, for rainfall $>50 \mathrm{~mm} \mathrm{day}^{-1}$, the decrease of the number of wet days in January since 1974 is of $100 \%$ and $-76 \%$ in the annual time scale (Table IX).

In Oran, a decrease in the number of wet days is observed for the 10-20 $\mathrm{mm}$ day $^{-1}$ class during December, March and April along with a decrease in the total number of wet days for the 20-50 $\mathrm{mm}$ day $^{-1}$ class (Table X). Overall, two of the rainfall classes (10-20 and 20$50 \mathrm{~mm}$ day $^{-1}$ ) experienced a significant change in temporal variability in the number of wet days at the Oran, Tenes, and Annaba stations.

\subsubsection{Relation between rainfall variability and at-} mospheric pressure

To understand the effect of atmospheric circulation on rainfall in northern Algeria, we analyzed the variability of sea level pressure (SLP) near Oran and Annaba. Data of SLP have been extracted from the site of the National Center for Atmospheric Research (https:// climatedataguide.ucar.edu/climate-data/ncar-sea-level-pressure). A standardized SLP index was computed over the study period and represented in the Fig. 4.
The Oran station is located at the western limit of the Mediterranean basin and is therefore influenced by Atlantic variations and the Azores anticyclones, which generally induce calm and dry weather (Taibi et al., 2017). The Annaba station is located in a transition zone between the western and eastern sides of the Mediterranean basin, influenced by ENSO and the Asian monsoon (Rodwell and Hoskins, 1996; Rodo et al., 1997; Price et al., 1998; Reale et al., 2001).

Pettitt's test shows a positive trend of SLP in Oran since 1973 (Fig. 4). The positive phase corresponds to higher atmospheric pressure affected by the Azores anticyclone, associated with dry weather and low rainfall variability over the Mediterranean basin. Thus it appears that pressure variability over the western region has affected rainfall variability by decreasing rainfall since the 1970s.

In the eastern region, SLP variability near Annaba does not significantly change (Fig. 4), in correlation with no significant change in rainfall variability for the Annaba time series during the reference period (1961-1990).

To explain rainfall variability in the Mediterranean basin, several authors have tried to find links with the

Table IX. Trend of the frequency of wet days for each month at Tenes.

\begin{tabular}{|c|c|c|c|c|c|c|c|c|c|c|}
\hline $\begin{array}{l}\text { Rainfall } \\
\text { interval } \\
\left(\mathrm{mm} \mathrm{day}^{-1}\right)\end{array}$ & Pettitt test & Oct & Nov & Dec & Jan & Feb & Mar & Apr & May & Total \\
\hline $1<\mathrm{R}<5$ & $\begin{array}{l}\text { Year of break } \\
\text { Mean before } \\
\text { Mean after } \\
\text { Difference }(\%)\end{array}$ & $\begin{array}{l}- \\
- \\
-\end{array}$ & $\begin{array}{l}- \\
- \\
-\end{array}$ & $\begin{array}{c}1973 \\
3.6 \\
1.5 \\
-58 \\
\end{array}$ & $\begin{array}{l}- \\
- \\
-\end{array}$ & $\begin{array}{l}- \\
- \\
-\end{array}$ & $\begin{array}{l}- \\
- \\
-\end{array}$ & $\begin{array}{l}- \\
- \\
-\end{array}$ & $\begin{array}{l}- \\
- \\
-\end{array}$ & $\begin{array}{c}1973 \\
22.15 \\
16 \\
-28 \\
\end{array}$ \\
\hline $5<\mathrm{R}<10$ & - & - & - & - & - & - & - & - & - & - \\
\hline $10<\mathrm{R}<20$ & $\begin{array}{l}\text { Year of break } \\
\text { Mean before } \\
\text { Mean after } \\
\text { Difference }(\%)\end{array}$ & $\begin{array}{l}- \\
- \\
-\end{array}$ & $\begin{array}{l}- \\
- \\
-\end{array}$ & $\begin{array}{l}- \\
- \\
-\end{array}$ & $\begin{array}{l}- \\
- \\
-\end{array}$ & $\begin{array}{l}- \\
- \\
-\end{array}$ & $\begin{array}{l}- \\
- \\
-\end{array}$ & $\begin{array}{l}- \\
- \\
-\end{array}$ & $\begin{array}{l}- \\
- \\
-\end{array}$ & $\begin{array}{c}1973 \\
12.23 \\
7.24 \\
-41\end{array}$ \\
\hline $20<\mathrm{R}<50$ & $\begin{array}{l}\text { Year of break } \\
\text { Mean before } \\
\text { Mean after } \\
\text { Difference (\%) }\end{array}$ & $\begin{array}{l}- \\
- \\
-\end{array}$ & $\begin{array}{l}- \\
- \\
-\end{array}$ & $\begin{array}{l}- \\
- \\
-\end{array}$ & $\begin{array}{l}- \\
- \\
-\end{array}$ & $\begin{array}{l}- \\
-\end{array}$ & $\begin{array}{l}- \\
-\end{array}$ & $\begin{array}{c}1978 \\
1.056 \\
0.167 \\
-84\end{array}$ & $\begin{array}{l}- \\
- \\
-\end{array}$ & $\begin{array}{l}- \\
-\end{array}$ \\
\hline $\mathrm{R}>50$ & $\begin{array}{l}\text { Year of break } \\
\text { Mean before } \\
\text { Mean after } \\
\text { Difference (\%) }\end{array}$ & $\begin{array}{l}- \\
- \\
-\end{array}$ & $\begin{array}{l}- \\
-\end{array}$ & $\begin{array}{l}- \\
- \\
-\end{array}$ & $\begin{array}{l}1974 \\
0.385 \\
0.001 \\
-100\end{array}$ & $\begin{array}{l}- \\
-\end{array}$ & $\begin{array}{l}- \\
-\end{array}$ & - & $\begin{array}{l}- \\
- \\
-\end{array}$ & $\begin{array}{c}1974 \\
1.833 \\
0.44 \\
-76\end{array}$ \\
\hline
\end{tabular}


Table X. Trend of the frequency of wet days for each month at Oran.

\begin{tabular}{|c|c|c|c|c|c|c|c|c|c|c|}
\hline $\begin{array}{l}\text { Rainfall interval } \\
\left(\mathrm{mm} \mathrm{day}^{-1}\right)\end{array}$ & Pettitt test & Oct. & Nov. & Dec. & Jan. & Feb. & Mar. & Apr. & May & Total \\
\hline $1<\mathrm{R}<5$ & - & - & - & - & - & - & - & - & - & - \\
\hline $5<\mathrm{R}<10$ & - & - & - & - & - & - & - & - & - & - \\
\hline $10<\mathrm{R}<20$ & $\begin{array}{l}\text { Year of break } \\
\text { Mean before } \\
\text { Mean after } \\
\text { Difference }(\%)\end{array}$ & $\begin{array}{l}- \\
- \\
-\end{array}$ & $\begin{array}{l}- \\
- \\
-\end{array}$ & $\begin{array}{c}1976 \\
1.6 \\
0.9 \\
-45\end{array}$ & $\begin{array}{l}- \\
- \\
-\end{array}$ & $\begin{array}{l}- \\
- \\
-\end{array}$ & $\begin{array}{c}1976 \\
1.533 \\
0.667 \\
-56\end{array}$ & $\begin{array}{c}1979 \\
1.3 \\
0.4 \\
-71\end{array}$ & $\begin{array}{l}- \\
- \\
-\end{array}$ & $\begin{array}{c}1976 \\
8.8 \\
6.1 \\
-30 \\
\end{array}$ \\
\hline $20<\mathrm{R}<50$ & $\begin{array}{l}\text { Year of break } \\
\text { Mean before } \\
\text { Mean after } \\
\text { Difference }(\%)\end{array}$ & $\begin{array}{l}- \\
- \\
-\end{array}$ & $\begin{array}{l}- \\
- \\
-\end{array}$ & $\begin{array}{l}- \\
- \\
-\end{array}$ & $\begin{array}{l}- \\
- \\
-\end{array}$ & $\begin{array}{l}- \\
- \\
-\end{array}$ & $\begin{array}{l}- \\
- \\
-\end{array}$ & $\begin{array}{l}- \\
- \\
-\end{array}$ & $\begin{array}{l}- \\
- \\
-\end{array}$ & $\begin{array}{l}1976 \\
4.00 \\
2.60 \\
-35\end{array}$ \\
\hline $\mathrm{R}>50$ & - & - & - & - & - & - & - & - & - & \\
\hline
\end{tabular}
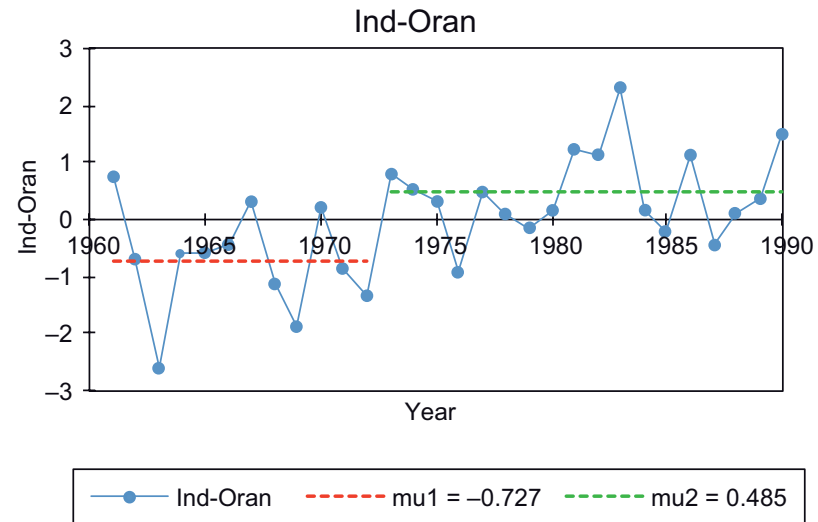

Fig. 4. SLP index variability at Oran and Annaba.

general atmospheric circulation. Numerous studies have highlighted the influence of the North Atlantic Oscillation (NAO) and the Mediterranean Oscillation (MO) on the variability of precipitation, especially in winter (Maheras et al., 1999; Xoplaki et al., 2004; Dünkeloh and Jacobeit, 2003; López and Frances, 2010; Brandimarte et al., 2011). Taibi et al. (2017) found that seasonal rainfall in northern Algeria is significantly correlated to the NAO and MO indices, while stations located in the eastern region of northern Algeria do not show significant correlations with the NAO, MO and SOI climate indices, which confirms the results observed on the variability of SLP at the Oran and Annaba stations.

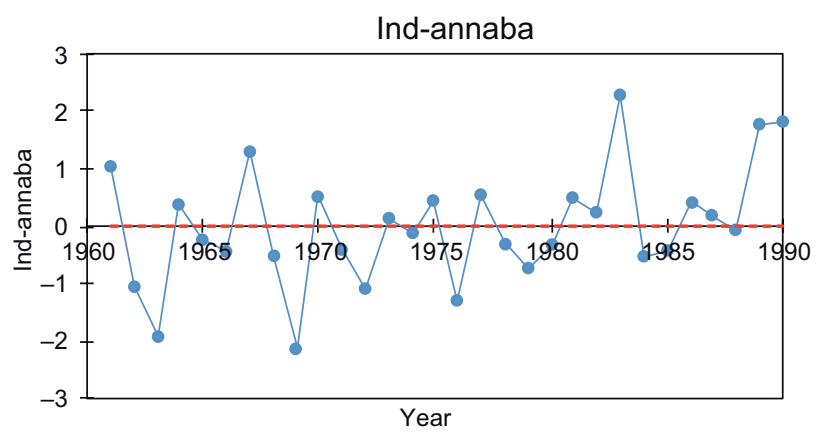

\subsection{Evaluation of the ENSEMBLES-RCM output rainfall}

The comparison of the observed and simulated rainfall of 12 RCMs during the 1961-1990 reference period shows an underestimation/overestimation of rainfall in the wet season/dry season (summer) (Fig.5). The same results are observed in other studies in the Mediterranean basin (Zanis et al., 2008; Coppola and Giorgi, 2010; Bargaoui et al., 2014; Ceglar et al., 2014).

In autumn (SON), most of the RCMs underestimate the rainfall at all stations. The ICTP is the only model that overestimates rainfall in all stations, reaching 100\% in Oran. Rainfall at the Oran station 

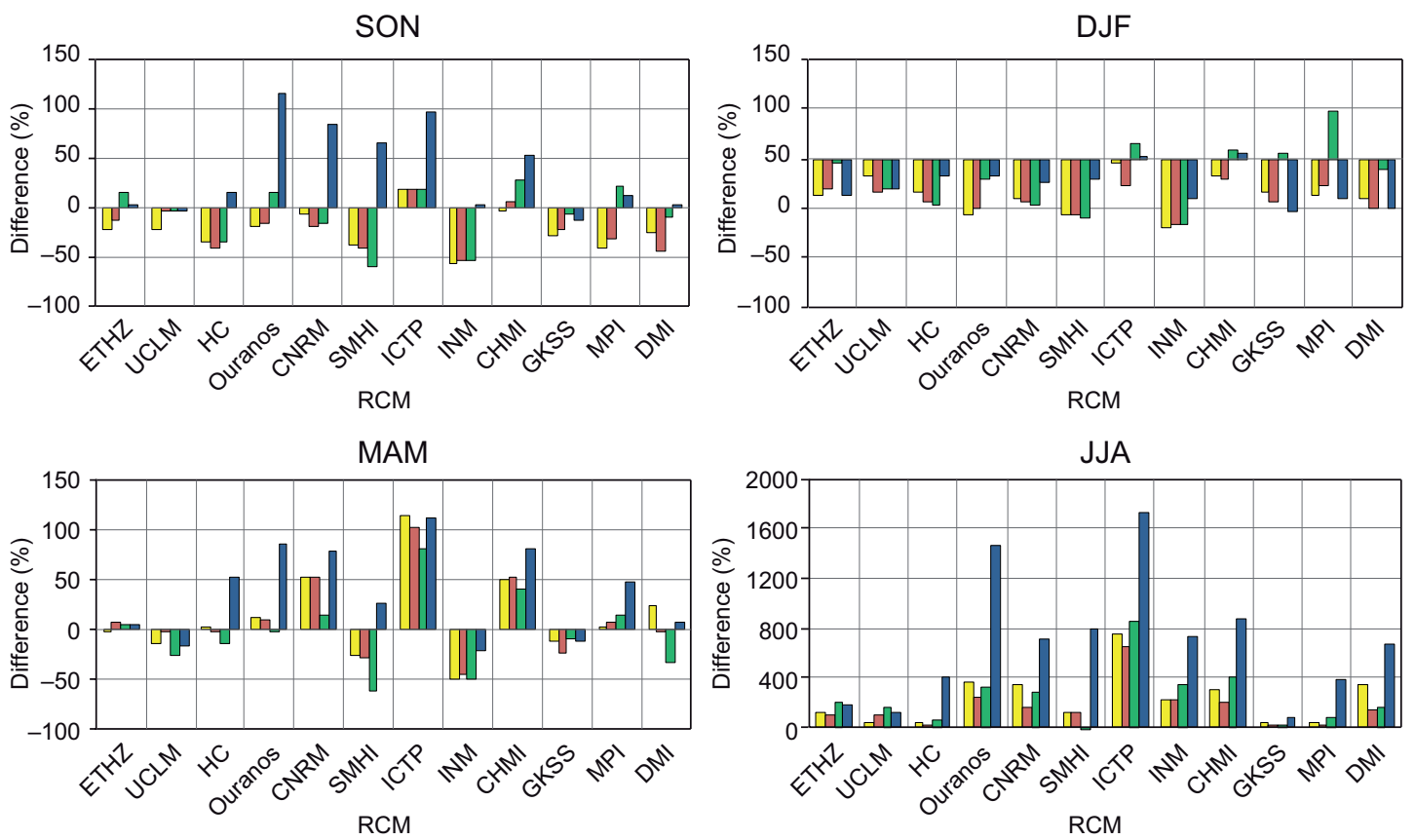

$\square$ Algiers $\square$ Annaba $\square$ Tenes $\square$ Oran

Fig. 5. Difference between simulated and observed seasonal rainfall during the reference period 1961-1990.

is also greatly overestimated by the OURANOS, CNRM, SMHI, and CHMI models with a bias that exceeds 50\%. The ETHZ, UCLM, CNRM, CHMI, GKSS, and DMI models exhibit a bias below 30\% for most stations in autumn. For each station, three RCMs were selected with the lower bias, i.e., theoretically the most efficient future rainfall simulation at each station. These are CHMI, CNRM and ICTP for the Algiers station; UCLM, CHMI and ETHZ for the Annaba station; and UCLM, GKSS and DMI for Tenes. The ETHZ, UCLM, and DMI models give simulation results for rainfall that are very close to the observed rainfall in Oran with a bias that does not exceed $2 \%$.

In winter (DJF), the majority of the RCMs tend to underestimate precipitation. The OURANOS, SMHI, INM, and DMI models strongly underestimate rainfall for the majority of stations with a bias that exceeds 50\%. The ICTP, CHMI and UCLM models better simulate the winter precipitation at the Algiers station. At Annaba, the CHMI, ICTP and MPI models are the least biased. The ETHZ, GKSS and CHMI models better simulate observed precipitation at Tenes, with a bias less than $10 \%$.
The ICTP, CHMI, and OURANOS models are the least biased at Oran.

In spring (MAM), the ICTP, CNRM, CHMI, and OURANOS models overestimate precipitations, especially the ICTP model characterized by a bias that generally exceeds $100 \%$. The rainfall simulated by the ETHZ, UCLM, HC, GKSS, OURANOS, and MPI models simulate rainfall with biases that do not exceed $20 \%$ for most stations. The ETHZ model accurately simulates spring rainfall along the Algerian coast.

In summer, the biases are very high. The majority of models greatly overestimate rainfall, although some of them perform well during other seasons (CNRM, ETHZ, and CHMI). The GKSS is the only model with low bias values for the summer season. Table XI summarizes the most efficient models for each season and station. Models perform differently at the same station during different seasons, and they differ from one station to another during the same season. CHMI is the most efficient model in winter and spring for all stations (except Tenes in autumn). It is therefore difficult to choose a single model that can reproduce simultaneously the spatial and temporal rainfall variability of the Algerian coast. 
Table XI. Efficient RCMs for each season and stations.

\begin{tabular}{lllll}
\hline Season & Autumn (SON) & Winter (DJF) & Spring (MAM) & Summer (JJA) \\
\hline Algiers & CHMI-CNRM-ICTP & ICTP-CHMI-UCLM & ETHZ-HC-MPI & UCLM-HC-GKSS \\
Annaba & CHMI-UCLM-ETHZ & ICTP-CHMI-MPI & UCLM-HC-DMI & GKSS-HC-MPI \\
Tenes & UCLM-GKSS-DMI & ETHZ-CHMI-GKSS & ETHZ-OURANOS-GKSS & HC-GKSS-SMHI \\
Oran & CHMI-CNRM-ETHZ & ICTP-CHMI-OURANOS & ETHZ-GKSS-DMI & GKSS \\
\hline
\end{tabular}

\subsection{Future evolution of seasonal rainfall}

Seasonal rainfall outputs of ENSEMBLES-RCM were analyzed during two projection periods, 2021 2050 and 2070-2099. The CNRM and ETHZ were the only models that efficiently simulated data during these two periods. Simulated data of the GKSS model were only available for the 2021-2050 the period.

The simulated seasonal rainfall of both projection periods was compared to simulated rainfall for the 1961-1990 reference period. The change in rainfall amounts is presented in Figure 6. The Kolmogorov-Smirnov (KS) test has been used to assess significant changes in projected seasonal rainfall. It is a non-parametric test that compares the cumulative distributions of two datasets. The KS test reports the maximum difference between the two cumulative distributions, and calculates a $p$-value. The null hypothesis is that both samples are from the same continuous distribution, and the $p$-value is superior to the significant level of $5 \%$. The alternative hypothesis is that both samples are from different continuous distributions and the $p$-value is inferior to the significant level. Results of a significant change of projected rainfall are presented in Figure 7. Overall, it appears that winter and spring show a significant reduction in rainfall (Fig. 7). In summer and autumn, some models project an increase in rainfall while others simulate a decrease, but this has little impact on the total annual rainfall because of the low amount of rainfall during this season (Fig. 6).

In autumn, the GKSS and CNRM models simulate a decrease in rainfall over the 2021-2050 period (Fig. 6) which is more significant in Algiers (GKSS), Oran (GKSS and CNRM) and Tenes (CNRM), while the ETHZ model indicates an increase in precipitation thet is more significant in the Annaba, Oran and Tenes stations (Fig. 7). In winter, all the models simulate a significant decrease in precipitation for all stations (Fig. 7). The precipitation change ranges form 50 to $120 \mathrm{~mm}$ (Fig. 6). However, the decrease trend simulated by the ETHZ and GKSS models in Oran is not significant (Fig. 7) and is equal to 8 and $14 \mathrm{~mm}$, respectively.

In spring, all models simulate a significant reduction of rainfall (Fig. 7) except the GKSS, which simulates an increase in rainfall of about $50 \mathrm{~mm}$ in Annaba. The variation in rainfall is between 40 and $140 \mathrm{~mm}$ (Fig. 6).

In summer, significant reductions in rainfall are simulated in Algiers, Oran and Tenes by the ETHZ and CNRM models, while the GKSS model simulates a significant increase in rainfall in Algiers, Oran and Tenes.

During the projected period (2070-2099) simulations follow the same trend as in the 2021-2050 period. In winter and spring the reduction of precipitation is even more important over the 2021-2050 period. In autumn, the decrease is usually greater, and increased rainfall simulated by the ETHZ model is less important than in the 2021-2050 period.

In summer the simulations vary between models and stations. The reduction or increase in rainfall during the 2070-2099 period may be more or less important than in the 2021-2050 period.

\section{Discussion}

The analysis of rainfall variability during the reference period (1961-1990) shows a negative trend in the west and a positive trend in the east of northern Algeria. Taïbi et al. (2013) analyzed more than 100 rainfall series over northern Algeria and demonstrated a significant decrease of annual rainfall in northwestern Algeria since the 1970s and 1980s, while rainfall variability in the eastern region did not change. Other studies also showed a decrease in rainfall in northwest Algeria (Meddi and Hubert, 2003; Medjerab et Henia, 2005; Meddi and Meddi, 2007; Meddi and 

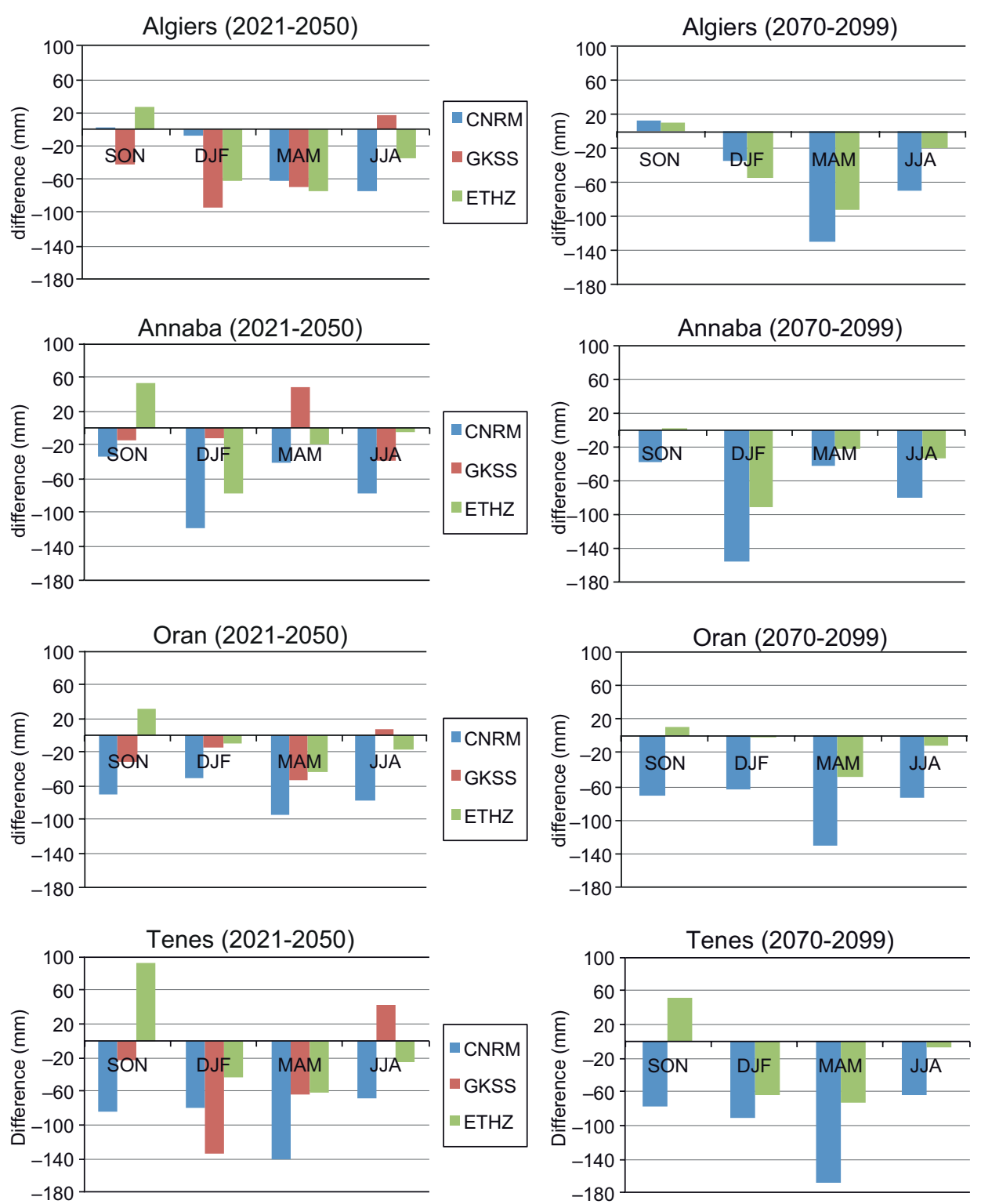

Fig. 6. Seasonal precipitation change between the two projected periods, 2021-2050 and 2070-2099, and the reference period 1961-1990.

Talia, 2007; Bekkoussa et al., 2008; Meddi et al., 2010; Taibi and Souag, 2011) and other regions of the Mediterranean basin such as Spain (de Luis et al., 2000; Sinoga et al., 2011), Italy (Longobardi et Villani, 2009; Caloiero et al., 2011), Greece (Xoplaki et al., 2000; Feidas et al., 2007) Morocco (Benassi, 2001; Singla et al., 2010) and Tunisia (Kingumbi et al., 2005).

Several studies correlate rainfall variability in the Mediterranean basin with the influence of general atmospheric circulation (van Oldenborgh et al., 2000; Lloyd-Hughes and Saunders, 2002; Knippertz et al., 2003; Xoplaki et al., 2004; López and Frances, 2010; Brandimarte et al., 2011). Meddi et al. (2010) and Taibi et al. (2017) highlighted a relationship between El Niño Southern Oscillation (ENSO) and annual rainfall variability over northwestern Algeria.

The decrease of monthly rainfall observed in western Algeria (Tenes and Oran) while the Annaba station located in the east of the study area recorded 

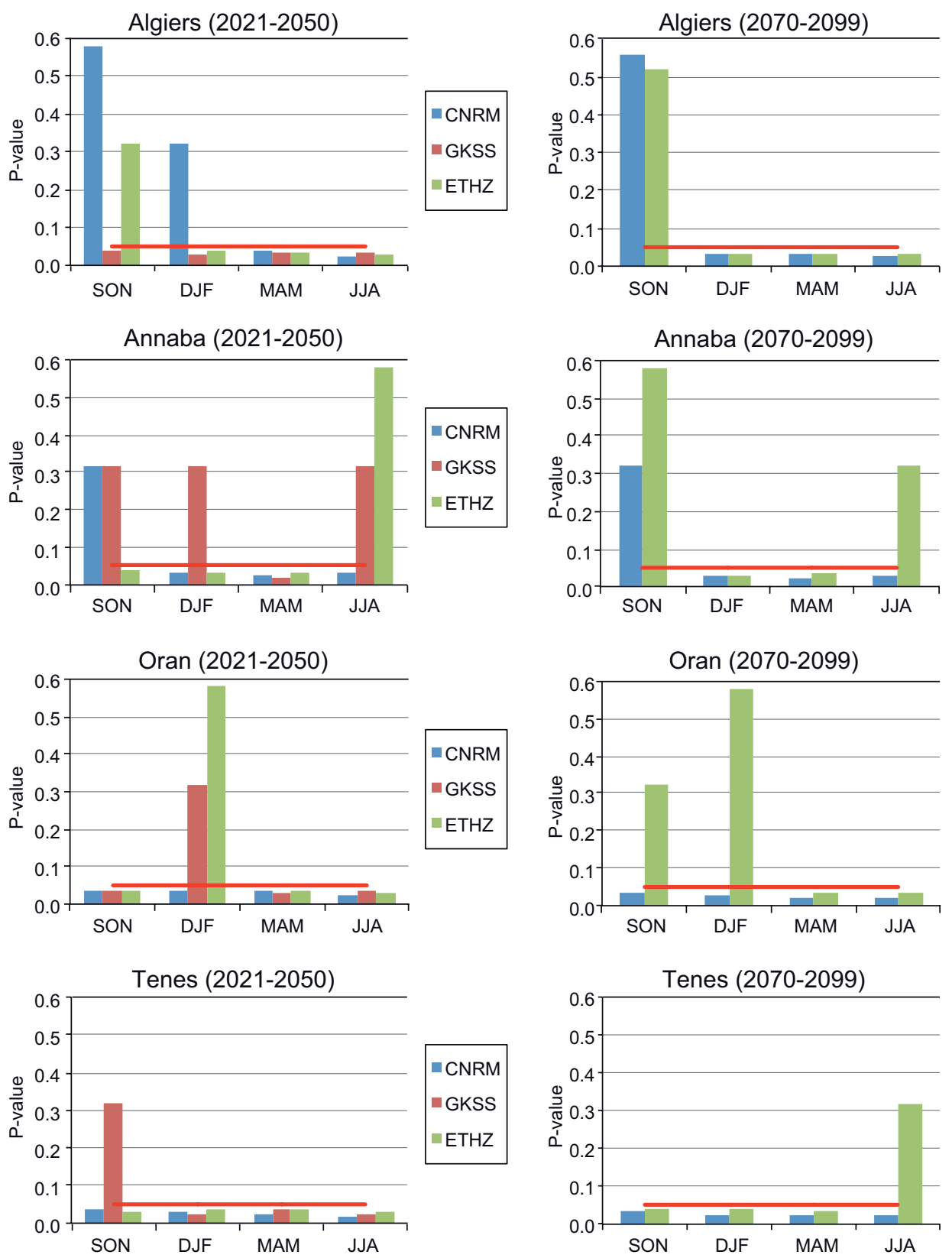

Fig. 7. Variation of p-value according to the Kolmogorov-Smirnov test (significance level of 0.05 is represented by a red line).

an increase of monthly rainfall during the study period reflect the opposite effect of atmospheric circulation on the rainfall over the two sides of the Algerian coastline. Indeed, some studies highlighted the influence of general atmospheric circulation on winter rainfall over the Mediterranean basin, particularly the influence of the North Atlantic Oscillation and the Mediterranean oscillation (Dünkeloh and
Jacobeit, 2003; Xoplaki et al., 2004; López and Frances, 2010; Brandimarte et al., 2011). Taibi et al. (2017) found a significant relation between monthly rainfall in northwestern Algeria and the Mediterranean Oscillation.

Rainfall variability in northern Algeria is correlated to a variation in the number of wet days ranging from 10 to $50 \mathrm{~mm}$, leading to a negative/ 
positive rainfall trend in the west/east since the $1970 \mathrm{~s}$, whereas the frequency of $R>50 \mathrm{~mm}$ has decreased in Tenes and Algiers since 1974. Taibi et al. (2017) also found a relationship between the evolution of the number of wet days over time and two atmospheric circulation indexes, the ENSO and the Mediterranean Oscillation. The SLP evolution at the opposite east and west extremities of northern Algeria show a relationship between pressure and rainfall variability, most probably through the effect of the Azores anticyclone, which diminishes rainfall in the western region of Algeria. The increase of monthly rainfall and the number of wet days observed in November and March at the Annaba station may be explained by a strong anomaly of pressure around the region such as the low pressures that prevail in the Gulf of Genoa.

The comparison between observed and simulated rainfall of 12 RCMs during the 1961-1990 reference period shows an underestimation of rainfall in the wet season and an overestimation of rainfall in the summer dry season. The same results are observed in other studies of the Mediterranean basin (Zanis et al., 2008; Coppola et Giorgi, 2010; Bargaoui et al., 2014; Ceglar et al., 2014; Alemseged and Tom, 2015). Climate change projections are subject to uncertainty arising from climate model deficiencies, unknown initial conditions and scenario assumptions. Paeth et al. (2016) showed that future precipitation variability in the Mediterranean basin is almost completely attributable to the uncertainty and internal variability of the model, both being equally important. Giménez et al. (2016) evaluated the performance of two new approaches based on the reliability ensemble averaging (REA) method for producing RCM ensembles of monthly precipitation in Spain. The proposed methodologies are based on probability density functions (PDFs) considering the variability of different levels of information on one hand, and of annual and seasonal rainfall and of monthly rainfall on the other hand.

Three models have been validated over the 19611990 reference period. Seasonal rainfall variability simulated by the CNRM, ETHZ, and GKSS models show a negative trend over two projected periods, 2021-2050 and 2070-2099, which is more important during winter and spring. These results are similar to some studies on the Mediterranean basin (Zanis et al., 2008; Giorgi and Coppola, 2010; Ceglar et al., 2014) that show a reduction of future seasonal rainfall in winter and summer. Furthermore, Hertig and Tramblay (2016) highlighted an increase in drought severity and occurrence for the whole Mediterranean region over the 2070-2100 period.

\section{Conclusions}

The aim of this study is to analyze the past and future evolution of seasonal rainfall variability in northern Algeria. The analysis of monthly rainfall variability during the 1961-1990 reference period revealed a significant decrease in rainfall since the 1970 s at the Tenes and Oran stations, located in northwest Algeria, which occurs during winter (December and January) and spring (March and April) associated to a decrease in the frequency of wet days in the 10-20 and $20-50 \mathrm{~mm} \mathrm{day}^{-1}$ rainfall classes. The eastern region recorded an increase in rainfall. This study has shown the influence of pressure on rainfall variability. The Azores anticyclone strongly influences rainfall in the western region of Algeria. The topography also plays an important role in the spatial distribution of precipitation in northern Algeria.

The assessment of the ENSEMBLES model outputs for rainfall in northern Algeria by comparing the simulated rainfall of $12 \mathrm{RCMs}$ and the observed data during the reference period showed that the majority of models tend to underestimate/overestimate rainfall during the wet/dry period, which affects the distribution of wet days between both periods. The models simulate rainfall differently from one season to another and from one station to another.

To deepen this study, investigations should be conducted particularly to explain the underestimation of models. Some factors must be considered such as the density of the observation network, hence requiring more stations for a better inter-comparison of the models at the scale of the study area. The analysis of projected rainfall by three models, CNRM, ETHZ and GKSS, over the periods 2021-2050 and 2070-2099, allows to compare various models for the same stations (temporal variability), as well as projections simulated by a model from one station to another (spatial variability). Models simulate a significant decline in rainfall during winter and spring for 2050, which worsens in 2099. In autumn, the ETHZ model simulates an increase in precipitation at all stations, while the CNRM and GKSS models 
simulate a decrease. In summer, the GKSS model simulates an increase in rainfall for all stations and the CNRM and ETHZ models indicate a decrease in precipitation. These conflicting results prevent us from reaching a definitive conclusion from model predictions for the studied areas.

It is important to consider the uncertainties affecting the results of this study, which relate to the RCMs and parameterization, and also to the quality of observed data and the uncertainties due to station location on the RCM grids.

\section{References}

Alemseged T.H. and Tom R., 2015. Evaluation of regional climate model simulations of rainfall over the Upper Blue Nile basin. Atmos. Res. 162, 57-64.

DOI: 10.1016/j.atmosres.2015.03.013

Bargaoui Z., Tramblay Y., Lawin E. A. and Servat E., 2014. Seasonal precipitation variability in regional climate simulations over Northern basins of Tunisia. Int. J. Climatol. 34, 235-248. DOI:10.1002/joc.3683

Bekkoussa B., Meddi M. and Jourde H., 2008. Forçage climatique et anthropique sur la ressource en eau souterraine d'une région semi-aride: Cas de la plaine de Ghriss (Nord-Ouest algérien). Sécheresse 18, 173-184.

Benassi M., 2001. Drought and climate change in Morocco. Analysis of precipitations field and water supply. Options Mediterranéennes Série A, 80, 83-86.

Brandimarte L., Di Baldassarre G., Bruni G., D’Odorico P. and Montanari A., 2011. Relation between the North Atlantic oscillation and hydroclimatic conditions in Mediterranean areas. Water Resour. Manag., 25 12691279. DOI 10.1007/s11269-010-9742-5

Caloiero T., Coscarelli R., Ferrari E. and Mancini M., 2011. Precipitation change in Southern Italy linked to global scale oscillation indexes. Nat. Hazards Earth Syst. Sci. 11, 1683-1694. DOI:10.5194/nhess-11-1683-2011

Ceglar A., Honzak L., Žagar N., Skok G., Žabkar R. and Rakovec J., 2014. Evaluation of precipitation in the ENSEMBLES regional climate models over the complex orography of Slovenia. Int. J. Climatol. 35, 2574-2591. DOI: $10.1002 /$ joc. 4158

Coppola E. and Giorgi F., 2010. An assessment of temperature and precipitation change projections over Italy from recent global and regional climate model simulations. Int. J. Climatol. 30, 11-32.

DOI: $10.1002 /$ joc. 1867
De Luis M., Ravento J., González-Hidalgo J.C., Sánchez J.R. and Cortina J., 2000. Spatial analysis of rainfall trends in the region of Vvalencia (east Spain). Int. J. Climatol. 20, 1451-1469. DOI:10.1002/10970088(200010)20:12<1451::AID-JOC547>3.0.CO;2-0

Driouech F., Mahé G., Déqué M., Dieulin C., El Heirech T., Milano M., Benabdelfadel H. and Rouché N., 2010. Evaluation d'impacts potentiels de changements climatiques sur l'hydrologie du bassin versant de la Moulouya au Maroc. In: Global change: Facing risks and threats to water resources. Proceedings of the Sixth World FRIEND Conference, Fez, Morocco, October. IAHS Publ. 340, 561-567.

Dubois C., Somot S., Calmanti S., Carillo A., Déqué M., Dell'Aquilla A., Elizalde-Arellano A., Gualdi S., Jacob D., Lheveder B., Li L., Oddo P., Sannino G., Scoccimarro E. and Sevault F., 2012. Future projections of the surface heat and water budgets of the Mediterranean Sea in an ensemble of coupled atmosphere-ocean regional climate models. Clim. Dynam. 39, 1859-1884. DOI: $10.1007 / \mathrm{s} 00382-011-1261-4$

Dünkeloh A. and Jacobeit J., 2003. Circulation dynamics of Mediterranean precipitation variability 1948-98. Int. J. Climatol. 23, 1843-1866. DOI: 10.1002/joc.973

Feidas H., Noulopoulou Ch., Makrogiannis T. and Bora-Senta E., 2007. Trend analysis of precipitation time series in Greece and their relationship with circulation using surface and satellite data 1955-2001. Theor. Appl. Climatol. 87, 155-177.

DOI: $10.1007 / \mathrm{s} 00704-006-0200-5$

Filahi S., Tramblay Y., Mouhir L. and Diaconescu E.P., 2017. Projected changes in temperature and precipitation indices in Morocco from high-resolution regional climate models. Int. J. Climatol. 37, 4846-4863.

DOI: $10.1002 /$ joc. 5127

Giménez P.O., Galiano S.G.G. and Giraldo-Osorio J.D., 2016. Identifying a robust method to build RCMs ensemble as climate forcing for hydrological impact models. Atmos. Res. 175, 31-40.

DOI: $10.1016 /$ j.atmosres.2016.01.012

Giorgio F. and Lionello P., 2008. Climate change projections for the Mediterranean region. Global Planet. Change 63, 90-104.

DOI: $10.1016 /$ j.gloplacha.2007.09.005

Hertig E. and Tramblay Y., 2016. Regional downscaling of Mediterranean droughts under past and future climatic conditions. Global Planet. Change 151, 36-48.

DOI: 10.1016/j.gloplacha.2016.10.015 
Hoerling M. P. and Kumar A., 2002. Atmospheric response patterns associated with tropical forcing. J. Climate, 15, 2184- 2203.

DOI : $10.1175 / 1520-0442(2002) 015<2184$ :ARPAW$\mathrm{T}>2.0 . \mathrm{CO} ; 2$

IPCC, 2007. Climate Change 2007: Synthesis Report. Contribution of Working Groups I, II and III to the Fourth Assessment Report of the Intergovernmental Panel on Climate Change (Core Writing Team, Pachauri R.K and Reisinger A. Eds.). IPCC, Geneva, Switzerland, 104 pp.

Khomsi K., Mahe G., Sinan M., Snoussi M., Cherifi R. and Nait Said Z., 2012. Evolution des évènements chauds rares et très rares dans les bassins versants du Tensift et du Bouregreg (Maroc) et identification des types de temps synoptiques associés. In: From Prediction to Prevention of Hydrological Risk in Mediterranean Countries (Ferrari E. and Versace P., Eds.). 4th International Workshop on Hydrological Extremes. University of Calabria, Cosenza, Italy, 169-182.

Kingumbi A., Bargaoui Z. and Hubert P., 2005. Investigation of the rainfall variability in central Tunisia. Hydrol. Sci. J. 50, 493-508. DOI: 10.1623/hysj.50.3.493.65027 Knippertz P., Ulbrich U., Marques F. and Corte-Real J., 2003. Decadal changes in the link between El Niño and spring time North Atlantic Oscillation and European-North African rainfall. Int. J. Climatol. 23, 1293-1311. DOI: $10.1002 /$ joc. 944

Laborde J., 1998. Rainfall maps of Northern Algeria at the scale of 1/500 000. Sheet memoir. National Agency of Hydraulic Resources, project PNUD/ALG/88/021.

Lloyd-Hughes B. and Saunders M.A., 2002. Seasonal prediction of European spring precipitation from El Niño-Southern Oscillation and local sea surface temperatures. Int. J. Climatol. 22, 1-14.

DOI: $10.1002 /$ joc. 723

Longobardi A. and Villani P., 2009. Trend analysis of annual and seasonal rainfall time series in the Mediterranean area. Int. J. Climatol. 30, 1538-1546.

DOI: $10.1002 /$ joc. 2001

López J. and Frances F., 2010. Influence of the North Atlantic Oscillation and the western Mediterranean oscillation in the maximum flow events in Spain. International Workshop on Advances in Statistical Hydrology, Taormina, Italy, 23-25 may, 1-11.

Maheras P., Xoplaki E. and Kutiel H., 1999. Wet and dry monthly anomalies across the Mediterranean Basin and their relationship with correlation, 1860-1990. Theor. Appl. Climatol. 64, 189-199.

DOI: $10.1007 / \mathrm{s} 007040050122$

Majone B., Bovolo C.I., Bellin A., Blenkinsop S. and Fowler H.J., 2012. Modeling the impacts of future climate change on water resources for the Gallego river basin (Spain).Water Resour. Res. 48, W01512. DOI: 10.1029/2011WR010985

Meddi H. and Meddi M., 2007. Variabilité spatiale et temporelle des précipitations du Nord-Ouest de l'Algérie. Géographia Technica 2, 49-55.

Meddi H. and Meddi M., 2009. Variabilité des précipitations annuelles du Nord-Ouest de l'Algérie. Sécheresse 20, 57-65.

Meddi M. and Hubert P., 2003. Impact de la modification du régime pluviométrique sur les ressources en eau du Nord-Ouest de l'Algérie. Hydrology of the Mediterranean and Semi-Arid Regions. IAHS Publ. 278, 1-7.

Meddi M. and Talia A., 2007. Pluviometric regime evolution in the North of Algeria. Arab Gulf Journal of Scientific Research 27, 152-162

Meddi M., Assani A.A. and Meddi H., 2010. Temporal variability of annual rainfall in the Macta and Tafna catchments, Northwestern Algeria. Water Res. Manage. 24, 3817-3833.

DOI: $10.1007 / \mathrm{s} 11269-010-9635-7$

Meddi M., 2013. Sediment transport and rainfall erosivity evolution in twelve basins in central and western Algeria. Journal of Urban and Environmental Engineering 7, 253-263.

Medjerab A. and Henia L., 2005. Régionalisation des pluies annuelles dans l'Algérie Nord-Occidentale. Revue Géographique de l'Est 45/2.

Milano M., Ruelland D., Fernández S., Dezetter A., Fabre J. and Servat E., 2012. Facing global changes in the Mediterranean basin. How could the current water stress evolve by the medium-term? C. R. Geosciences 344, 432-440. DOI: 10.1016/j.crte.2012.07.006

Milano M., Ruelland D., Fernández S., Dezetter A., Fabre J., Servat E., Fritsch J.-M., Ardoin-Bardin S. and Thivet G., 2013. Current state of Mediterranean water resources and future trends under global changes. Hydrolog. Sci. J. 58, 498-518. DOI: $10.1080 / 02626667.2013 .774458$

Paeth H., Vogt G., Paxian A., Hertig E., Seubert S. and Jacobeit J., 2016. Quantifying the evidence of climate change in the light of uncertainty exemplified by the 
Mediterranean hot spot region. Global and Planetary Change 151, 144-151.

DOI: 10.1016/j.gloplacha.2016.03.003

Pettitt A.N., 1979. A non-parametric approach to the change-point problem. Appl. Stat.-J. Roy. St. C 28, 126-135. DOI: $10.2307 / 2346729$

Price C., Stone L., Rajagopalan B. and Alpert P., 1998. A possible link between El Nino and precipitation in Israel. Geophys. Res. Let. 25, 3963-3966.

DOI: 10.1029/1998GL900098

Quintana Seguí P., Ribes A., Martin E., Habets F. and Boé J., 2010. Comparison of three downscaling methods in simulating the impact of climate change on the hydrology of Mediterranean basins. J. Hydrol. 383, 111-124. DOI: 10.1016/j.jhydrol.2009.09.050

Reale O., Feudale L. and Turato B., 2001. Evaporative moisture sources during a sequence of floods in the Mediterranean region. Geophys. Res. Let. 28, 2085 2088. DOI: 10.1029/2000GL012379

Rodo X., Baert E. and Comin F.A., 1997. Variations in seasonal rainfall in Southern Europe during the present century: relationships with the North Atlantic Oscillation and the El Niño-Southern Oscillation. Clim. Dynam. 13, 275-28.

DOI: $10.1007 / \mathrm{s} 003820050165$

Rodwell M.J. and Hoskins B.J., 1996. Monsoons and the dynamics of deserts. Q. J. Roy. Met. Soc. 122, 13851404. DOI: $10.1002 /$ jj. 49712253408

Sánchez-Gómez E., Somot S. and Mariotti A., 2009. Future changes in the Mediterranean water budget projected by an ensemble of regional climate models. Geophys. Res. Lett. 36, L21401. DOI: 10.1029/2009GL040120

Senatore A., Mendicino G., Smiatek G. and Kunstmann H., 2011. Regional climate change projections and hydrological impact analysis for a Mediterranean basin in Southern Italy. J. Hydrol. 399, 70-92.

DOI: 10.1016/j.jhydrol.2010.12.035

Singla S., Mahé G., Dieulin C., Driouech F., Milano M., El Guelai F.Z. and Ardoin-Bardin S., 2010. Evolution des relations pluie-débit sur des basins versants du Maroc. In: Global change: Facing risks and threats to water resources. Proceedings of the Sixth World FRIEND Conference, Fez, Morocco, October. IAHS Publ. 340, 679-687.
Sinoga J.D.R, Marín R.G., Murillo J.F.M. and Galeote M.A.G., 2011. Precipitation dynamics in southern Spain: Trends and cycles. Int. J. Climatol. 31, 22812289. DOI: $10.1002 /$ joc. 2235

Taibi S. and Souag D., 2011. Regionalization of drought in Northern Algeria using a standardized precipitation index (1936-2010). In: From prediction to prevention of hydrological risk in Mediterranean countries. 4th International Workshop on Hydrological Extremes. University of Calabria, Cosenza, Italy, 169-182.

Taibi S., Meddi M., Souag D. and Mahe G., 2013. Évolution et régionalisation des précipitations au nord de 1>Algérie (1936-2009). In: Climate and land surface changes in hydrology. IAHS Publ. 359, 191-197.

Taibi S., Meddi M., Mahé G. and Assani A. 2017. Relationships between atmospheric circulation indices and rainfall in Northern Algeria and comparison of observed and RCM-generated rainfall. Theor. Appl. Climatol. 127, 241-257.

DOI: $10.1007 / \mathrm{s} 00704-015-1626-4$

Tramblay Y., Badi W., Driouech F., El Adlouni S., Neppel L. and Servat E., 2012. Climate change impacts on extreme precipitation in Morocco. Global Planet. Change 82-83: 104-114.

DOI: $10.1016 /$ j.gloplacha.2011.12.002

Van Oldenborgh G.J., Burgers G. and Tank A.K., 2000. On the El Niño teleconnection to spring precipitation in Europe. Int. J. Climatol. 20, 565-574.

DOI: 10.1002/(SICI)1097-0088(200004)20:5< 565::AID-JOC488>3.0.CO;2-5

Xoplaki E., Luterbacher J., Patrikas J. and Maheras P., 2000. Les précipitations hivernales en Grèce et leurs relations avec la circulation atmosphérique au niveau de $500 \mathrm{hPa}$. Climate. Res. 14, 129-146.

Xoplaki E., González-Rouco J.F., Luterbacher J. and Wanner H., 2004. Wet season Mediterranean precipitation variability: influence of large-scale dynamics and trends. Clim. Dynam. 23, 63-78.

DOI: $10.1007 / \mathrm{s} 00382-004-0422-0$

Zanis P., Kapsomenakis I., Philandras C., Douvis K., Nikolakis D., Kanellopoulou E., Zerefos C. and Repapis C., 2008. Analysis of an ensemble of present day and future regional climate simulations for Greece. Int. J. Climatol. 29, 1614-1633. DOI: 10.1002/joc.1809 